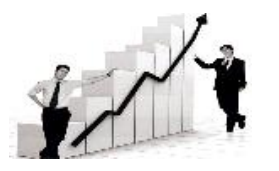

Visit Us - www.researchjournal.co.in

DOI : 10.15740/HAS/IRJAES/6.1/155-159

International Research Journal of Agricultural Economics and Statistics

Volume 6 | Issue 1 | March, 2015 | 155-159 | e ISSN-2231-6434 |

\title{
Research Paper Impact of futures trading on spot prices of mustard in the state of Rajasthan
}

\section{B.L. VERMA AND R.C. KUMAWAT}

See end of the paper for authors' affiliations

\section{Correspondence to :}

\section{B.L. VERMA}

Department of Agricultural Economics, S.K.N. College of Agriculture, JOBNER (RAJASTHAN) INDIA

Paper History : Received : 15.03.2014; Revised : 30.01.2015: Accepted : 17.02.2015
ABSTRACT : In this investigation an attempt has been made to study the impact of futures trading on spot prices of mustard seed in the state of Rajasthan. For this purpose secondary data on futures prices collected from the annual reports of the commodity exchange for the financial years 2003 to 2008 and on spot prices collected from Krishi Upaj Mandi, Bikaner for the financial years 2000 to 2008 were used. The period prior to futures trading was designated as pre futures period (PI) and that of futures trading as futures period (PII). Growth in monthly prices was estimated with the help of exponential function and trend by fitting of quadratic function. Impact of futures trading on spot prices was captured by employing dummy variable technique. Integration among futures and spot markets was studied by computing simple correlation between prices. All the prices futures, spot market and mandi spot prices for mustard seed recorded significant growth of the order of 0.57 per cent, 0.42 per cent and 0.43 per cent, respectively, during the study period. The trend in all these prices of mustard seed was noted to be curvi linear in shape during the study period, i.e., concave downwards. The significantly high value of ' $\mathrm{F}$ ' statistic for mustard seed suggested that $\mathrm{T}$ and $\mathrm{T}^{2}$ jointly had significant effect on prices $(\mathrm{P})$. The study also revealed that the futures trading affected the slope of spot prices of mustard seed, i.e., rate of change in the spot prices, without affecting the mean price level. This meant that the regressions were concurrent in nature. Thus it may be inferred that futures prices of mustard reduced the rate of change in the spot prices of the crop in the futures period. The futures market and the spot market were noted to be highly integrated (0.9140) in respect of the mustard seed.

KEY WORDS : Futures prices, Spot prices, Growth, Trend, Mustard seed

HOW TO CITE THIS PAPER : Verma, B.L. and Kumawat, R.C. (2015). Impact of futures trading on spot prices of mustard in the state of Rajasthan. Internat. Res. J. Agric. Eco. \& Stat., 6 (1) : 155-159. 